\title{
Adam Stecyk
}

Katedra Efektywności Innowacji

Wydział Zarządzania i Ekonomiki Usług

Uniwersytet Szczeciński

\section{E-learning i blended learning w edukacji. Charakterystyka projektu LAMS WZiEU}

\section{E-learning i blended learning w przedsiębiorstwie}

Dynamicznie zmieniająca się rzeczywistość stawia przed współczesnymi organizacjami nowe wyzwania. Globalizacja rynków, gospodarka oparta na wiedzy, społeczeństwo informacyjne, wzrost poziomu konkurencyjności - to przenikające się nawzajem czynniki determinujące zachowanie i funkcjonowanie społeczności, przedsiębiorstw i klientów. Firmy stawiające sobie za cel odniesie sukcesu rynkowego powinny rozumieć współzależność owych czynników i umiejętnie je wykorzystywać.

Upowszechnienie nowych technologii teleinformatycznych wywołuje zmiany nie tylko w funkcjonowaniu przedsiębiorstw, ale także w strukturach organizacyjnych, powodując nowy podział zadań, obowiązków i kompetencji, a co za tym idzie - dowodzi kluczowej roli edukacji w strategii firmy. W dobie internetu szkolenia tradycyjne są wspomagane (a czasem częściowo lub całkowicie zastępowane) przez rozwiązania elektroniczne. W literaturze przedmiotu nazywa się to zdalnym nauczaniem lub e-learning (w przypadku wykorzystywania form tradycyjnych i elektronicznych - blended learning, czyli nauczanie mieszane lub komplementarne). Coraz więcej polskich firm interesuje się nowoczesnymi technologiami wspomagającymi i optymalizującymi procesy edukacyjne; niektóre $\mathrm{z}$ nich mają już za sobą pierwsze próby wykorzystania innowacyjnych systemów zdalnego nauczania. Na świecie zarówno e-learning, jak i blended learning ewoluują z poziomu nowej idei do szeroko rozpowszechnionego, praktycznego i racjonalnego sposobu kształcenia.

Nie istnieje jedna, uniwersalna definicja określenia e-learning. Najogólniej można je scharakteryzować jako kontrolowaną metodę przekazywania wiedzy (najczęściej na odległość), opartą na mediach elektronicznych. Szkolenia blended learning zaś są definiowane jako połączenie szkoleń tradycyjnych z elektronicznymi (nauczanie mieszane), z zastrzeżeniem różnorakich form kształcenia w zależności od specyfiki przedmiotu (treści szkoleniowej). Nowoczesne e-nauczanie prowadzone jest on-line lub off-line w wewnętrznej sieci placówki szkolącej (intranet) lub poprzez sieć zewnętrzną (internet), a ostatnio także poprzez telefonię komórkową (m-learning, ang. mobile learning), często $\mathrm{z}$ wykorzystaniem dodatkowych zasobów na nośnikach informacji (CD-ROM, DVD itp.). Innymi słowy, e-learning i blended learning to „nowoczesny sposób na przekazywanie wiedzy, kontrolę procesu kształcenia oraz pozyskiwania informacji zwrotnej o przyswojeniu wiedzy przez studenta". ${ }^{1}$ Zależność pomiędzy nauczaniem tradycyjnym a elektronicznym przedstawia ryc. 1.

W literaturze przedmiotu bardzo często wymieniane są głównie zalety e-nauczania, do których zalicza się brak ograniczeń terytorialnych, dużą elastyczność form szkoleniowych oraz

\footnotetext{
${ }^{1}$ http://www.elearningzone.pl
} 
efektywność ekonomiczną inwestycji w e-kursy. Warto jednak wskazać także bariery wykorzystania nowoczesnych technologii w edukacji, ze szczególnym uwzględnieniem polskiej rzeczywistości:

Ryc. 1. Współczesny model kształcenia²

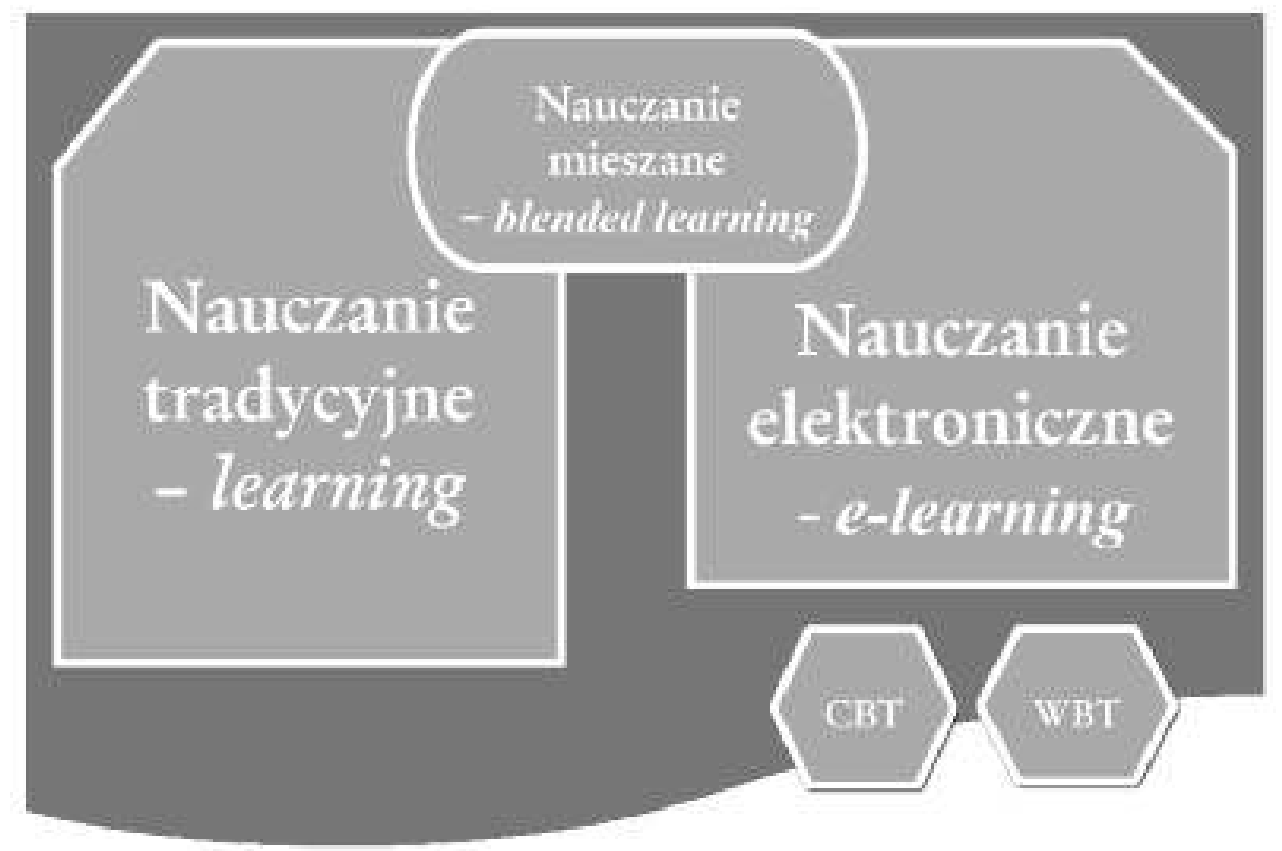

Źródło: opracowanie autora.

- Bariera finansowa - budżet organizacji i zmiany w istniejącym, zaplanowanym na kilka lat budżecie (także w dziedzinie szkoleń).

- Bariera mentalna - naturalna obawa przed zmianami wszystkich zainteresowanych grup (studentów, tutorów, autorów treści, ewaluatorów, informatyków i techników, zarządu organizacji).

- Bariera organizacyjno-technologiczna - nowa technologia, rozumiana jako nowe (nieznane) rozwiązanie informatyczne lub tradycyjno-informatyczne. Przepustowość łączy internetowych w Polsce.

Systemowe podejście do nauczania elektronicznego wskazuje, że projekt typu e-learning powinien być rozpatrywany w ujęciu organizacyjno-finansowym, technologiczno-przestrzennym (infrastrukturalnym) i ludzkim. Posługując się dekompozycją systemu typu e-learning (rozumianego jako zbiór wszystkich elementów składowych projektu, a nie system informatyczny), szczegółowe zagadnienia e-nauczania należy rozpatrywać na trzech płaszczyznach, przy założeniu ich silnego wzajemnego przenikania:

- informatycznej,

- merytorycznej,

- metodologicznej.

E-learning realizuje więc funkcje systemów wspomagających nauczanie i zarządzanie treścią; przygotowywanie, udostępnianie i monitorowanie procesu nauki, oferując jednocześnie innowacyjne podejście do nauczania i administrowania treścią dydaktyczną.

Charakteryzując zagadnienie e-learningu, należy się skoncentrować na trzech podstawowych elementach: wiedzy (usługi dydaktyczne), ludziach (lider, projektanci, nauczyciele, uczestnicy szkoleń), komunikacji (dystrybucja szkoleń). Z tego punktu widzenia rodzi się pytanie: W jaki

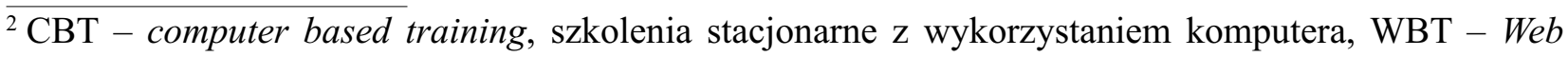
based training, szkolenia sieciowe. 
sposób najbezpieczniej wdrażać nowoczesne rozwiązania e-learning, tak aby poznać ich skuteczność i przydatność dla przedsiębiorstwa i nie ponosić zbyt wysokich kosztów wdrażania. Odpowiedzią może być ewolucyjna metoda małych kroków, zastosowana w projekcie LAMS WZiEU realizowanym na Wydziale Zarządzania i Ekonomiki Usług Uniwersytetu Szczecińskiego.

Ryc. 2. Wzajemne relacje elementów projektu typu e-learning

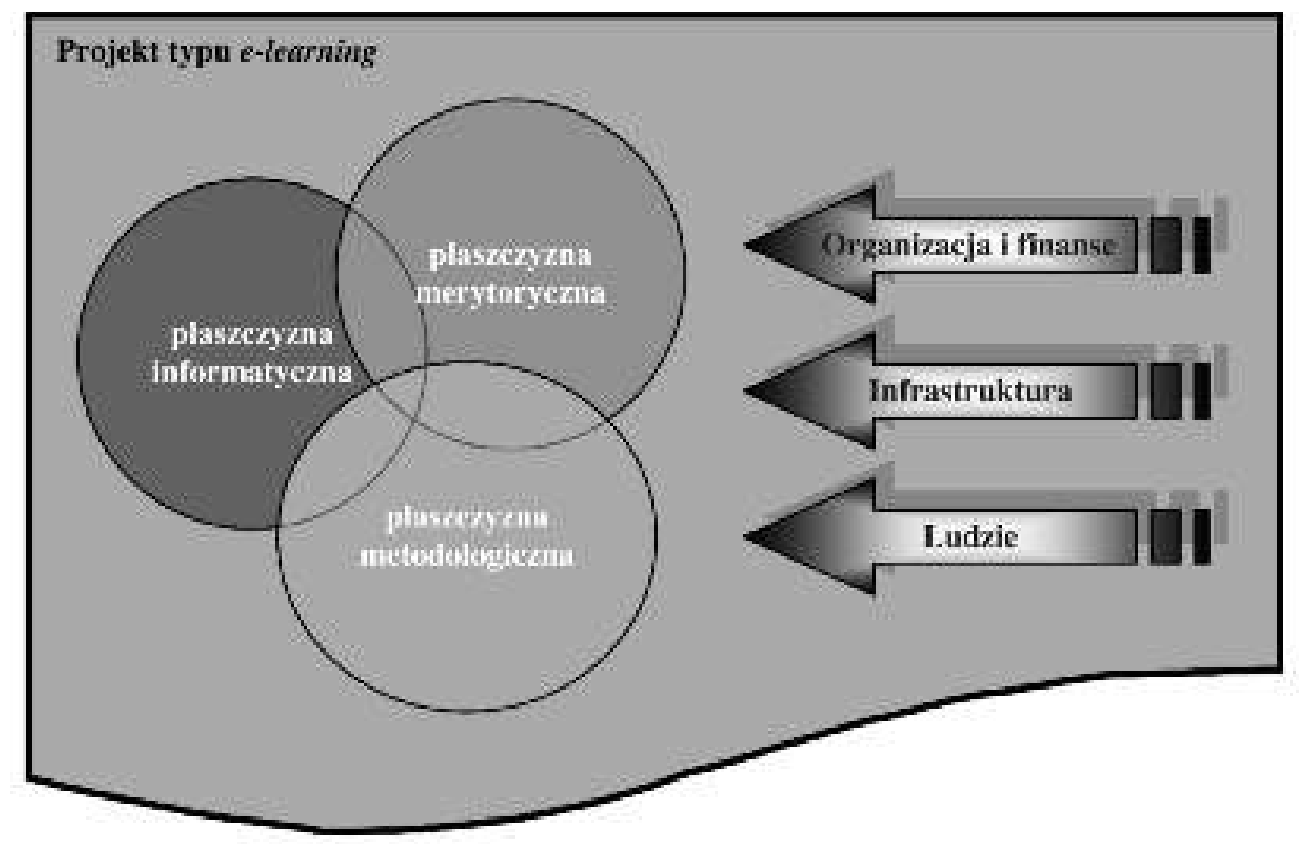

Źródło: opracowanie autora.

\section{Projekt LAMS WZiEU. Blended learning w praktyce}

Projekt LAMS WZiEU powstał w 2006 r., kiedy został nawiązany kontakt pomiędzy Katedrą Efektywności Innowacji Wydziału Zarządzania i Ekonomiki Usług US a E-learning Institute MELCOE Innowacyjnego Uniwersytetu Macquarie w Sydney. Efektem współpracy był wyjazd jednego z pracowników katedry na stypendium naukowe do Australii, stworzenie polskiej wersji językowej systemu LAMS $^{3}$ i pierwsze w Polsce wdrożenie australijskiej platformy do zastosowań e-learning i blended learning.

$\mathrm{Na}$ Wydziale Zarządzania i Ekonomiki Usług podstawową barierą była bariera finansowa, dlatego podczas początkowych prac nad projektem przyjęto następujące założenia:

- Głównym modelem kształcenia będzie model blended learning, umożliwiający połączenie nauczania tradycyjnego z nowoczesnymi narzędziami teleinformatycznymi.

- Platforma e-learning wykorzystywana na WZiEU musi być narzędziem bezpłatnym, ale spełniającym wymagania modelu blended learning. Po wstępnych konsultacjach ustalono, że będzie to bezpłatny (licencja GPL) otwarty system LAMS (Learning Activity Management System).

- Jednym z pierwszych zadań będzie dostosowanie systemu LAMS do polskich warunków (przede wszystkim stworzenie polskiej wersji językowej, które ukończono w styczniu 2007 r.).

- Wdrażanie filozofii e-nauczania będzie miało charakter ewolucyjny (metoda małych kroków) i będzie inicjatywą oddolną, tzn. będzie możliwe wtedy i tylko wtedy, gdy prowadzący zajęcia uznają, że system LAMS podnosi efektywność nauczania i poprawia organizację pracy.

- Pierwszym przedmiotem nauczanym w trybie blended learning będą podstawy informatyki, prowadzone w laboratoriach komputerowych od 1 października 2007 r.

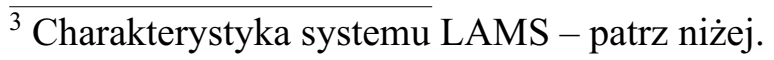


- Ze względu na wykorzystywaną platformę LAMS, projekt będzie nosił nazwę LAMS WZiEU, a jego charakterystyka znajdzie się w specjalnym serwisie internetowym, powiązanym ze stronami internetowymi WZiEU.

Pierwszym przedmiotem opracowanym w formie blended learning są podstawy informatyki; praca dzieli się na:

1. wykłady - zajęcia teoretyczne prowadzone w sposób tradycyjny, w wymiarze 15 godzin w semestrze; weryfikacja wiedzy teoretycznej w laboratoriach komputerowych w systemie LAMS w formie testu e-learning;

2. laboratoria - zajęcia praktyczne prowadzone w laboratoriach komputerowych w wymiarze 45 godzin lekcyjnych. Tradycyjny zakres przedmiotu obejmuje zagadnienia wykorzystania podstawowych aplikacji biurowych (edytor tekstu, grafika prezentacyjna, arkusz kalkulacyjny, bazy danych, komunikacja internetowa). Nauczanie tradycyjne obejmuje około $70 \%$ materiału, a praca własna studenta w systemie LAMS - około 30\%.

Platforma e-larning została wykorzystana do następujących zastosowań:

- wyrównywanie poziomu wiedzy bazowej (początkowej) studentów, dotyczącej obsługi aplikacji biurowych - opracowanie graficznych przewodników, umożliwiających studentom z mniejszym doświadczeniem w użytkowaniu aplikacji biurowych szybkie przyswojenie podstawowej wiedzy, tak aby począwszy od drugich zajęć poziom zaawansowania wszystkich studentów był wyrównany;

- standaryzacja przekazywania wiedzy w formie tradycyjnej - wykorzystanie systemu LAMS podczas zajęć „na żywo” do prezentowania treści szkoleniowych w takim samym układzie (co nie oznacza, że tak samo) i realizację przyjętych zadań tego samego typu (co nie oznacza, że takich samych);

- praca własna studentów w formie e-nauczania - opracowanie sekwencji dydaktycznej umożliwiającej prezentację treści (graficzne przewodniki, tekstowe podsumowanie, tak aby studenci mogli kopiować notatki do notatnika - narzędzie systemu LAMS dla studentów) i jej weryfikację poprzez udostępnienie zadań i testów sprawdzających;

- komunikacja ze studentami - każda sekwencja dydaktyczna realizowana przez studenta $\mathrm{w}$ dowolnym czasie pomiędzy jednym a drugim spotkaniem $\mathrm{z}$ nauczycielem jest zaopatrzona w mechanizm komunikacji asynchronicznej (forum) do wymiany pytań, uwag i sugestii oraz mechanizm dostarczania wykonanych zadań (dokumentów określonych aplikacji) do nauczyciela (wysyłanie plików);

- weryfikacja wiedzy - możliwość monitorowania postępów studenta poprzez oceny zadań (wymiana dokumentów), podgląd i oceny wypowiedzi na forum, testy, ankiety i pytania otwarte umożliwiające weryfikację wiedzy zarówno cząstkowej (testy tygodniowe podczas pracy domowej studenta), jak i kompleksowej (np. test wiedzy teoretycznej z wykładów w systemie LAMS podczas zajęć laboratoryjnych).

Etap I projektu LAMS WZiEU został zakończony. Trwają prace analityczne i ewaluacyjne dotyczące zrealizowanego przedmiotu, ale ogólna ocena efektywności metod nauczania wykorzystujących nowoczesne narzędzia teleinformatyczne jest pozytywna w opinii zarówno nauczycieli, jaki i studentów. Nakłady poniesione przez Wydział Zarządzania i Ekonomiki Usług wydają się niewielkie w stosunku do osiągniętych wyników. Platforma LAMS nie jest narzędziem doskonałym, ale stanowi ciekawą alternatywę dla rozwiązań komercyjnych, zwłaszcza na początku stosowania e-learningu. W kwietniu 2008 r. rozpocznie się II etap 
projektu obejmujący: zakup i instalację nowego serwera e-learning, instalację kolejnej wersji systemu LAMS (z nowymi możliwościami nieliniowego projektowania procesów dydaktycznych), ewaluację przedmiotu podstawy informatyki oraz opracowanie dwóch kolejnych przedmiotów do nauczania w trybie blended learning.

\section{Charakterystyka systemu LAMS}

Jednym z systemów e-learning, który służy do realizacji koncepcji e-learning i blended learning, jest system LAMS - Learnig Activity Management System. Ogólna charakterystyka systemu została zaprezentowana na łamach e-mentora w artykule Charakterystyka funkcjonowania systemu LAMS (Learning Activity Management System), 2 (14)/2006; w tym miejscu przypominamy tylko jego najistotniejsze cechy:

1. System LAMS jest narzędziem rozwijanym na Uniwersytecie Macquarie w Sydney, dystrybuowanym na licencji GPL ${ }^{4}$.

2. Składa się z czterech głównych modułów, odpowiadających za: przygotowanie treści dydaktycznych (autor), organizowanie procesu dydaktycznego (administracja), naukę (student) oraz weryfikację rezultatów (monitor).

3. Może funkcjonować jako osobny, samodzielny system e-learning lub jako zintegrowany fragment większej całości, np. funkcjonującego już systemu LMS (LAMS jest w pełni zintegrowany zarówno z bezpłatnymi systemami MOODLE, Sakai, dotLRN, jak i z komercyjnym WebCT).

4. Z informatycznego punktu widzenia system LAMS działa w środowisku rozproszonym, wykorzystując architekturę klient-serwer. Podstawowe komponenty systemu to: serwer baz danych MySQL, platforma Java oraz interfejs wykorzystujący technologię FLASH.

Modułem odpowiedzialnym za przygotowanie treści (sekwencji) dydaktycznych w systemie LAMS jest moduł autora. Przed przystąpieniem do charakterystyki poszczególnych narzędzi autorskich, należy zaprezentować główne koncepcje wykorzystywane w systemie.

1. Aktywności dydaktyczne są reprezentowane przez prostokątne ikony, a przejścia między nimi - przez strzałki.

Ryc. 3. Aktywności, przejścia i bramy w systemie LAMS

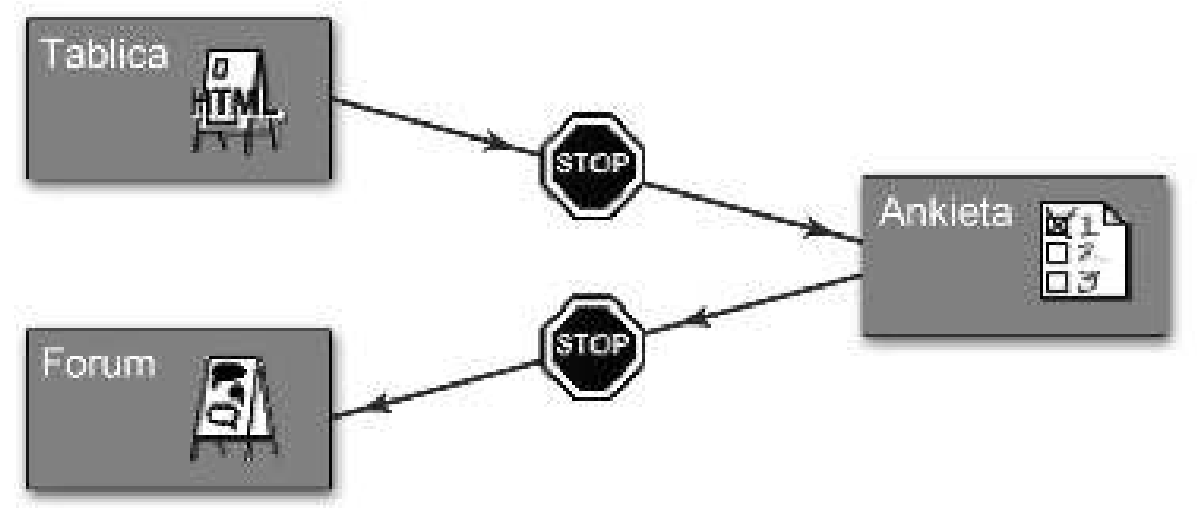

Źródło: LAMS 2.0

2. Przejścia od jednej aktywności do drugiej mogą być poprzedzone bramą, która determinuje ciągłość nauki. Występują trzy rodzaje bram: otwierana przez nauczyciela w czasie rzeczywistym (nauczyciel decyduje, w którym momencie udostępnić studentom kolejną aktywność), otwierana czasowo (zaprogramowane otwarcie (oraz zamknięcie) bramy na

${ }^{4}$ Co w praktyce oznacza, że jest bezpłatny. 
konkretny dzień i godzinę, brama synchroniczna (otwierana automatycznie, gdy wszyscy studenci ukończą aktywność poprzedzającą bramę). Bramy reprezentowane są przez czerwone ikony stopu.

3. Aktywności opcjonalne - nauczyciel może zdefiniować kilka aktywności i określić, ile (nie: które) z nich musi zostać zakończonych przez studenta, aby mógł on kontynuować naukę.

4. Grupowanie - losowe bądź dokonywane przez nauczyciela grupowanie studentów w celu wspólnej pracy w niewielkich zespołach.

5. „Zdefiniuj później”, czyli możliwość definiowania aktywności w czasie rzeczywistym przez nauczyciela podczas procesu dydaktycznego (studenci realizują wcześniejsze zadania lub czekają, aż nauczyciel przygotuje/zmodyfikuje następną aktywność.

6. Funkcjonalność systemu jest oparta na aplikacjach typowych dla środowiska Windows. Operacje dyskowe i edycyjne odbywają się w taki sam sposób, jak w znanych programach typu MS WORD czy MS EXCEL (ale interfejs programu jest zrealizowany za pomoca technologii FLASH).

7. Branching, czyli różne ścieżki dydaktyczne w zależności od osiągniętych wyników (np. studenci, którzy podczas testu uzyskali wynik 50\%, zostają skierowani na inną ścieżkę nauczania niż ci, którzy uzyskali wynik 75\%)

Przedstawione koncepcje wykorzystywane w systemie LAMS są wspomagane konkretnymi narzędziami do budowania treści dydaktycznych. Narzędzia te mają cechy wspólne, co powoduje, że znajomość jednego narzędzia ułatwia poznanie kolejnych:

1. Wbudowany edytor tekstowy (edytor HTML) umożliwiający budowanie treści dydaktycznych w różnych narzędziach w taki sam sposób (dodawanie zdjęć, zmiany formatu tekstu, praca z multimediami itp.).

2. Możliwość załadowania pliku z instrukcjami on-line lub off-line dla dowolnej aktywności.

3. Komentarz na temat narzędzia - funkcja, która umożliwia nauczycielowi uzyskanie komentarza dotyczącego konkretnej aktywności (ankiety, współdzielonego pliku, forum itp.).

4. Eksport/import przygotowanych treści dydaktycznych.

Narzędzia (aktywności) systemu LAMS (ryc. 3) dostępne w wersji 2.0:

1. ankieta - testy, quizy, ankiety;

2. czat - narzędzie do komunikacji synchronicznej;

3. forum - narzędzie do komunikacji asynchronicznej;

4. tablica - dowolna treść projektowana w edytorze systemu LAMS;

5. notatnik - zapiski studenta;

6. współdzielone zasoby - dowolny plik (np. arkusz kalkulacyjny), link do strony www w sieci internet lub przygotowana i spakowana do formatu zip strona www;

7. pytanie odpowiedź - zadawanie pytań studentom;

8. wielokrotny wybór - test wyboru, pytania z przypisanymi wagami;

9. „wyślij plik” - przesłanie nauczycielowi zrealizowanych zadań (np dokumenty tekstowe, prezentacje, arkusze kalkulacyjne).

Koncepcje i narzędzia wykorzystywane w module autora systemu LAMS wskazują na możliwość projektowania treści dydaktycznych opartego na znanych metodykach nauczania (behawioryzm, konstruktywizm itp.). Należy podkreślić, że system LAMS umożliwia prowadzenie zajęć w trybie synchronicznym oraz asynchronicznym i może być wykorzystywany do szkoleń on-line, w nauczaniu komplementarnym (mieszanym) i w tradycyjnym. 
Ryc. 4. Moduł autora w systemie LAMS

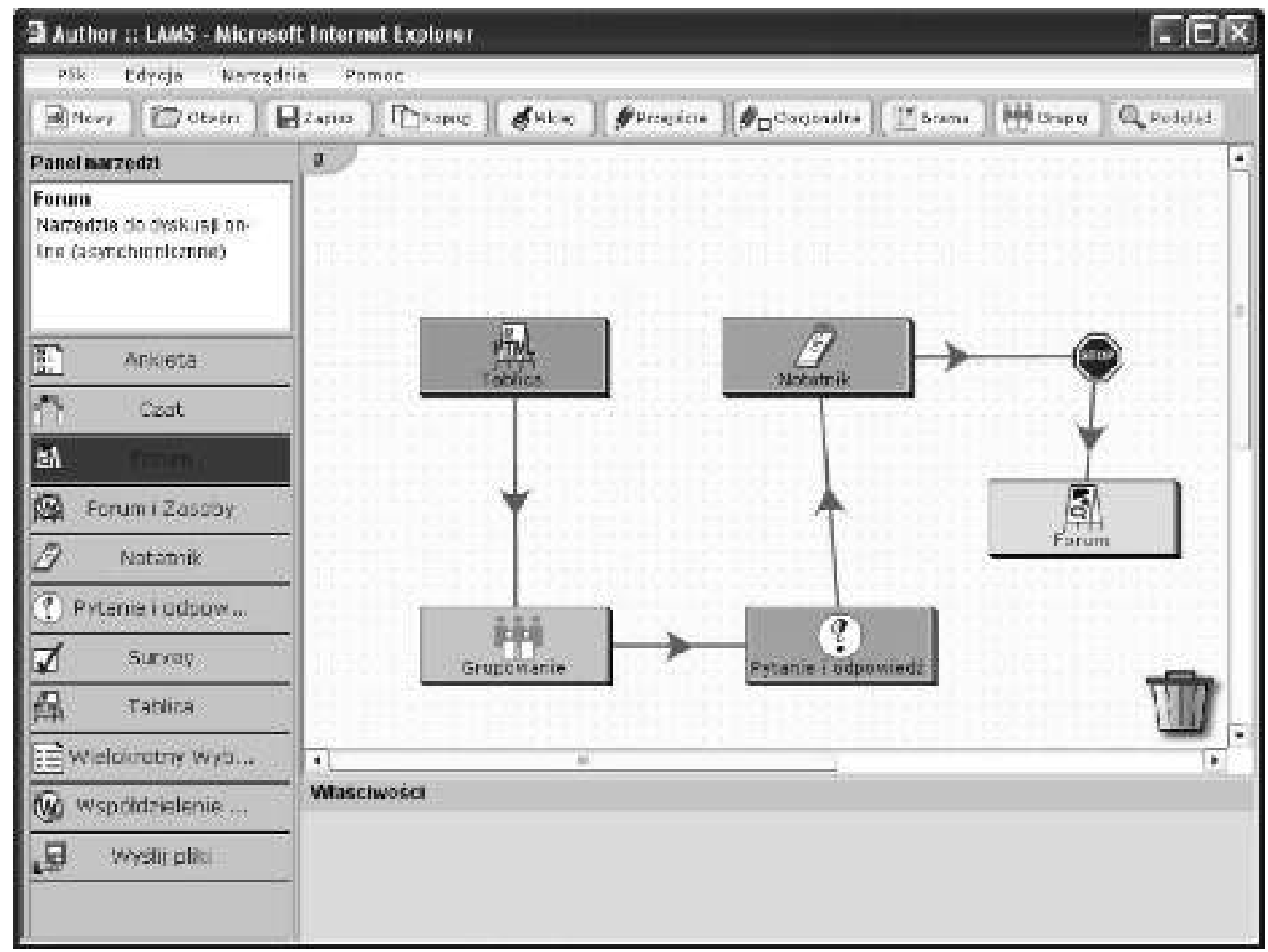

Źródło: LAMS 2.0

Reasumując, system LAMS, jako bezpłatny profesjonalny system e-learning, może stanowić alternatywę na drodze do e-nauczania, zwłaszcza dla małych i średnich organizacji. W przypadku spełnienia podstawowych warunków na płaszczyznach organizacyjno-technicznej i ludzkiej, implementacja systemu w organizacji nie sprawia kłopotu. Administrowanie systemem, tworzenie grup szkoleniowych i zarządzanie użytkownikami także odbywa się łatwo i intuicyjnie. Najtrudniejszym etapem jest opracowanie koncepcji szkoleniowej. Przygotowanie treści dydaktycznych powinno być poprzedzone merytoryczną analizą zagadnienia i wyborem formy nauczania, zarówno pod względem czasu, jak i sposobu przekazywania wiedzy.

Proces kształcenia wykorzystywany przez przedsiębiorstwa, organizacje sektora publicznego i jednostki edukacyjne ewoluuje. W skali globalnej wiele firm zmaga się z narastającym problemem niespełnionego zapotrzebowania na szkolenia. W dzisiejszej gospodarce opartej na wiedzy każde przedsiębiorstwo musi efektywnie poradzić sobie z obsługą, dystrybucją i absorbowaniem wiedzy, dlatego niezbędna jest znajomość nowoczesnych technologii teleinformatycznych (czego przykładem może być system LAMS), standardów e-nauczania oraz modeli budowania elektronicznych treści szkoleniowych. 


\section{E-learning and Blended Learning in Education. The LAMS WZiEU Project}

The paper presents the basic terms and functions of contemporary education model, its advantages and disadvantages and characteristic of e-learning projects. The second part shows free, open source e-learning system: LAMS (Learning Activity Management System), which could be an alternative for commercial tools. The third part describes results of LAMS WZiEU project - implementation of blended learning at the Faculty of Management and Economics of Services. 